\title{
Zofia Władyka-Łuczak*
}

\section{Inicjacja przekazu artystycznego}

Mieczysław Wallis przyznawał, że celem tworzenia dzieła sztuki jest wywołanie przeżyć estetycznych. Jednak do tego konieczna jest swoistego rodzaju nić porozumienia pomiędzy twórcą a odbiorcą. Aby ta nić zaistniała, niezbędne jest „rozumienie dzieła sztuki”, które Wallis definiuje „jako czynność intelektualną, dzięki której widziane lub słyszane przez nas dzieło sztuki staje się przy spełnieniu jeszcze szeregu innych warunków przedmiotem naszego przeżycia estetycznego i to takiego przeżycia estetycznego, jakie chciał wywołać w nas twórca tego dzieła”. „Inne warunki” to odpowiednio zorganizowane i podane przez artystę elementy postrzeżeniowe. Co ciekawe, uwarunkowania dziejowo-historyczne zmieniają interpretację danego dzieła sztuki².

Obecnie jesteśmy świadkami interesującego zjawiska nadawania dziełom rzeźbiarskim istniejącym w przestrzeni publicznej nowego znaczenia. Akcje happeningowe zainicjował Komitet Obrony Demokracji Regionu Zachodniopomorskiego 28 lipca 2018 roku, zawieszając na pomniku upamiętniającym postać prezydenta Lecha Kaczyńskiego koszulkę z napisem KONSTYTUCJA. Jak czytamy na oficjalnej stronie internetowej KOD,

[b]yła to forma zamanifestowania naszego przywiązania dla najważniejszych dla nas wartości, a także próba zwrócenia uwagi szerokiej opinii publicznej na fakt, że prezydent Andrzej Duda, mimo licznych protestów obywatelskich, podpisał się pod ustawą zmieniającą Sąd Najwyższy w kolejną - po Trybunale Konstytucyjnym

* Dr, Uniwersytet Łódzki, Wydział Filologiczny, Katedra Dziennikarstwa i Komunikacji Społecznej, e-mail: zofia.wladyka@uni.lodz.pl

1 M. Wallis, Przeżycie i wartość. Pisma z estetyki i nauki o sztuce 1931-1949, Wydawnictwo Literackie, Kraków 1968, s. 81.

2 Tamże, s. 81-82. 
i Krajowej Radzie Sądowniczej - atrapę. Ustawa ta bowiem jawnie łamie najwyższy akt prawny, jakim jest Konstytucja ${ }^{3}$.

Wkrótce podobne koszulki z napisem „KONSTYTUCJA” pojawiły się na wielu pomnikach w licznych polskich miastach. Jednym z nich był słynny pomnik "Syreny", który wszystkim jednoznacznie do tej pory kojarzył się z symbolem miasta, z herbem Warszawy, ale latem 2018 roku dodatkowo dostrzegliśmy w niej postać broniącą konstytucji. Pomnik, choćby tylko na chwilę, zmienił więc swoją wymowę, stając się rzeźbą opowiadającą zupełnie inną historię niż ta, do której przywykliśmy.

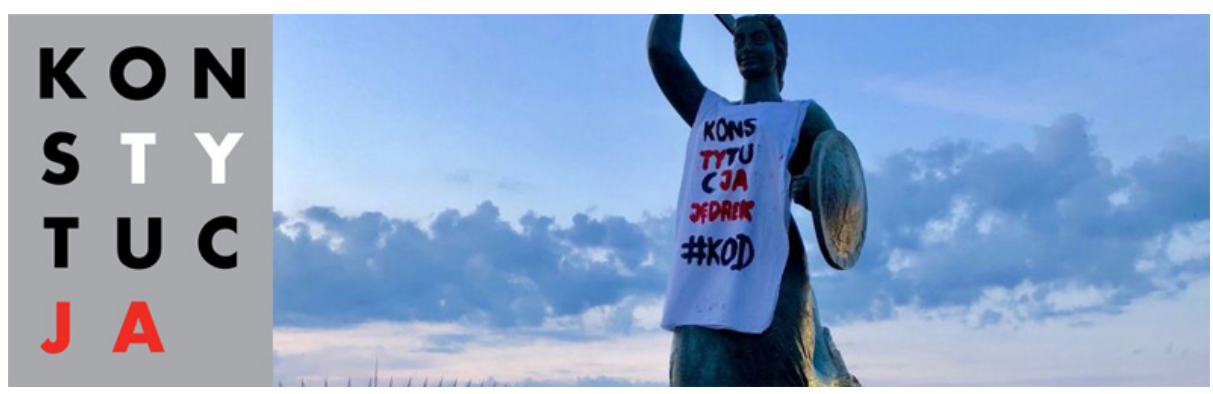

Fot. 1. Foto: KOD, https://www.ruchkod.pl [dostęp: 12.09.2018]. Po lewej stronie plakat „Konstytucja” Luka Rayskiego, po prawej stronie „Koszulka” na pomniku warszawskiej „Syreny” autorstwa Ludwiki Nitschowej.

Niezależnie od postawy, jaką przyjmujemy wobec tej akcji, nowa formuła wyrazu emocjonalnego istniejących już od dawna rzeźb jest czytelna dla wszystkich. Zrozumiałe jest, że przed wspomnianymi wydarzeniami miejskie rzeźby i plakat Luka Rayskiego „Konstytucja”, będący podstawą projektu koszulek, postrzeżeniowo istniały niezależnie od siebie. Połączono je chwilowo we wspólny przekaz na tak długo, jak długo będzie to społecznie ważne.

Zaistniała sytuacja sprowokowała mnie do postawienia pytania: Kiedy i z jakiego powodu pojawia się inicjacja przekazu artystycznego? Nie oceniam tu społecznej postawy wypowiedzi politycznej. Nieważne, kto i kiedy zainicjował opisany happening. W wydarzeniu tym odnotowałam chwilę inspiracji artystycznej. Istotna dla mnie stała się zdolność artystycznej ingerencji z zastaną rzeczywistością i zmiana pierwotnego znaczenia w zupełnie inne - nowe. Może dlatego, że i ja jako rzeźbiarz wciąż się borykam z problemem inicjacji wypowiedzi artystycznej.

W dziełach przedstawiających (odnoszących się do świata przedmiotów) nawet najdoskonalsze, najbardziej mistrzowskie odzwierciedlenie rzeczywistości nie

3 Oświadczenie Komitetu Obrony Demokracji, 3.08.2018, https://www.ruchkod.pl/oswiadczenie-komitetu-obrony-demokracji/ [dostęp: 20.08.2018]. 
jest jedynym celem artystów. Zwykle ważne jest dla nich takie połączenie wątków figuratywnych z innymi środkami wyrazu, by wywołać u odbiorcy swoiste odczucia estetyczno-emocjonalne. Zobrazowanie wycinka rzeczywistości należy zatem rozumieć jako nośnik estetyczno-emocjonalnej wartości, a nie jako dokonany akt.

Stopień zaawansowania przekazu oraz rozumienia intencji artysty zdaniem Władysława Strzemińskiego, twórcy Teorii widzenia, związany jest z dwustopniowym mechanizmem widzenia ${ }^{4}$. Pierwszy poziom to ewaluacja biologicznego aparatu widzenia - oka, drugi zaś to „świadomość widzenia”, rozumienie tego, „co człowiek uświadamia sobie z owego widzenia. Tylko to, co sobie uświadomił - to w rzeczywistości zobaczył. Reszta pozostaje poza jego świadomością nierozpoznana i dlatego niezauważona"s.

Kierując się teorią Strzemińskiego, chwilę uświadomienia tego, co dostrzegł aparat wzrokowy, można określić jako chwilę powstania inspiracji twórczej. Jest ona potrzebna obu stronom, tej, która zajmuje się tworzeniem i tej, która jest odbiorcą przekazu artystycznego.

Nieco inaczej problem ten charakteryzuje Michael Fleischer, który na podstawie odniesień do procesów komunikacji w ramach dywersyfikacji i dyferencjacji ukierunkowuje wynik działań poprzez stosowny dobór wybranych wariantów tychże działań. Różnica pomiędzy dywersyfikacją a dyferencjacją polega na tym, że w pierwszym przypadku do głosu dochodzą elementy z wewnątrz jednego systemu, jest zatem wewnątrzstrukturalna, $\mathrm{w}$ drugim przypadku istotna jest wielość systemów z coraz to nowymi elementami przez nie wyprodukowanymi ${ }^{6}$. Wielosystemowość, jak się zdaje, przesuwa „cel” na plan dalszy, który wyprzedza proces manifestacji komunikacji, w tym proces inicjacji przekazu artystycznego.

Fleischer za Georgem Spencerem-Brownem oraz Gregorym Batesonem przyjmuje, że „jakakolwiek aktywność miałaby miejsce, rozpoczyna się ona od rozróżnienia,

4 „Istnieją więc dwie ewolucje w zakresie widzenia. Jedną jest ewolucja naszego aparatu wzrokowego, rozwój oka, które było niegdyś - w najprostszych formach bytu - tylko skupieniem komórek skóry, bardziej uwrażliwionych na działanie światła niż inne komórki tej samej skóry. Poprzez rozmaite typy i odmiany stało się ono tym, czym jest obecnie - normalnym ludzkim okiem. [...] Obok tego pierwszego procesu istnieje proces drugi: rozwój umiejętności korzystania z widzenia" (W. Strzemiński, Teoria widzenia, Muzeum Sztuki w Łodzi, Łódź 2016, s. 51-52).

5 Tamże, s. 54.

6 M. Fleischer, Dwa rodzaje reprodukcji systemów - dywersyfikacja i dyferencjacja, w: Komunikatywizm w Polsce. Wybrane zagadnienia z teorii i praktyki, red. G. Habrajska, Primum Verbum, Łódź 2011, s. 222-223. Dywersyfikacja zdefiniowana jest tu jako „powielanie elementów systemu wraz z jego strukturą, rozumianą tu jako producent systemu; dywersyfikacja zatem odbywa się w ramach struktury”, dyferencjacja zaś jako „transportowanie elementów systemu i tworzenie w tym celu własnych struktur tych elementów; dyferencjacja zatem powstaje ze struktur i odbywa się między strukturami" (tamże, s. 221). 
a więc od obserwacji"'. Aktywność, obserwacja to zaczyn komunikacji, która staje się inicjacją do powstania nowych rzeczy ${ }^{8}$.

Niniejsza praca ma dotyczyć jedynie spraw związanych $\mathrm{z}$ „zaczynem komunikacji” w systemie sztuki. Określenie „zaczyn komunikacji” przemieniam w określenie „inicjacji przekazu artystycznego”, uznając go za bliższy dyskursowi artystycznemu. Jednocześnie uznaję za prawdziwe słowa Niklasa Luhmanna: „Obserwując dzieło sztuki, można zakładać, że artysta miał coś na myśli, gdy je tworzył, i można oglądać, że inni widzą, co sami sądzą o tym, że mógł on to coś mieć na myśli; to z kolei może skłonić artystę do mówienia o swojej twórczości"”.

W przygotowywanych do druku publikacjach: Relacje artysty za światem oraz Przestrzeń tworzenia poruszam aspekt obejmujący autoetnograficzne ujęcie własnej twórczości. Obie książki dotyczą autoobserwacji artysty-rzeźbiarza wykonującego pracę artystyczną. Różni je przyjęta postawa: w pierwszej jest to postawa obserwatora wewnętrznego, w drugiej - oberwatora zewnętrznego. Pozycja Relacje artysty za światem zbudowana jest $\mathrm{z}$ dwóch części: pierwszej, autorskiej retrospekcji przedstawiającej proces powstania jednej rzeźby: pomnika Rajmunda Rembielińskiego ${ }^{10}$, oraz drugiej, analizy tychże działań w ujęciu relacji społecznych twórcy z otaczającym go światem społecznym, wykonanej na podstawie etnograficznej analizy Clifforda Geertza.

Przestrzeń tworzenia powstała na kanwie teorii rozsądnego konstruktywizmu Fleischera. W podsumowaniu pracy został zawarty m.in. wniosek traktujący o tym, że tworzący w zależności od okoliczności, w jakich się znajduje, przyjmuje dwie postawy. Pierwszą można określić jako przedtwórczą, drugą zaś jako twórczą.

Postawa przedtwórcza to stan prowadzący do osiągnięcia właściwego celu - dojście do stanu inspiracji, postawa twórcza zaś to osiągnięcie stanu inspiracji. Stanu inspiracji nie należy mylić z realizacją tego, co zostało wymyślone. Chwila inspiracji, czyli olśnienia, natchnienia trwa krótko. Czas następny, realizacja wymyślonego, to tylko rzemiosło. W retrospekcji stan twórczy opisałam następująco:

Stanęłam przed sztalugą. Wiedziałam, że ten dzień jest dobry, a mimo to czułam irytację. To ważny znak, od niego zwykle zaczyna się u mnie proces tworzenia.

7 M. Fleischer, Kapitał niestety nie( )ludzki, Libron - Filip Lohner, Kraków 2014, s. 25.

8 „Rozróżnienia nie są pojmowane jako stany rzeczy (różnice), lecz że sprowadzają się one do wezwania, by ich dokonać, gdyż w innym przypadku nie można byłoby nic oznaczyć, a więc nie byłoby nic do obserwowania, a więc niczego nie można by kontynuować" (N. Luhmann za: M. Fleischer, Kapitał..., s. 26).

9 N. Luhmann, Pisma o sztuce i literaturze, Wydawnictwo Naukowe "Scholar”, Warszawa 2016, S. 119.

10 Rajmund Rembieliński, piastujący w latach 1816-1832 stanowisko Prezesa Komisji Województwa Mazowieckiego, stał się „ojcem” przemysłowej Łodzi. 
Zawsze tak jest. Irytacja, którą muszę opanować, dopilnować, by nie przerodziła się w złość, by wzmogła we mnie stan koncentracji. Nie wiem, co by się stało, gdyby w tym czasie ktoś wszedł, zadzwonił, czegoś ode mnie chciał. A może kiedyś tak było, tylko tego nie usłyszałam, nie zobaczyłam. Odcinam się od rzeczywistości. Mąż doskonale wie, kiedy nie powinien wchodzić do mojej części pracowni. Drzwi są zamknięte nawet przed nim.

To wspaniałe uczucie, gdy stawiane kreski stają się mocniejsze, pewniejsze. Synteza myśli przychodzi sama, bez udziału mojej woli. Ważne, by tych kresek nie było zbyt dużo, nie wolno postawić ani jednej więcej, niż jest to konieczne ${ }^{11}$.

W trakcie dalszych rozważań okazało się, że proces przebiegających po sobie zdarzeń to swoistego rodzaju zaczyn postrzeżeń, które z kolei mogą stać się przyczynkiem do wykreowania inicjacji twórczych. W ramach wymienionych postaw dają się wyróżnić dwie grupy procesów postrzeżeniowych: powstające spontanicznie (niezależne od woli twórcy) i prowokowane.

Twórca skazany jest na bezustanną obserwację otaczającej go rzeczywistości. We wstępie do mojego pierwszego katalogu Przekroczyć próg Janusz Głowacki pisał: „Jak wiadomo, artystą się nie jest, artystą się bywa. To długa droga doświadczeń, eksperymentów, ślepych uliczek, przygody ze światem i samym sobą" ${ }^{2}$. To, co Głowacki określił jako „doświadczenie” i „przygodę”, ja rozumiem jako rozpoczęcie procesu „inicjacji przekazu artystycznego”. Niejednokrotnie doświadczyłam, że aby narysować, wyrzeźbić fragment natury, należy wcześniej nauczyć się tego fragmentu na pamięć. Przejście przez proces oglądu i zapamiętania obserwowanej rzeczywistości to niezbędny etap prowadzący do powstania wypowiedzi artystycznej. Nie chodzi tu oczywiście tylko o sztukę przedstawiającą. Dzieła abstrakcyjne, jak je ogólnie nazywamy, wymagają nie tylko szerokiej wiedzy, ale i (a może przede wszystkim) interpretacji tego, co artysta zauważył wokół siebie.

Strzemiński w Teorii widzenia wyjaśnia, że wraz z historycznym rozwojem świadomości wiedzy o rzeczywistości wzrasta ludzka świadomość widzenia. Następuje samonapędzający się rozwój, swoistego rodzaju perpetuum mobile tego, co postrzegamy, jak przetwarzamy i rozumiemy. Nic dziwnego, im więcej rozumiemy, tym więcej przetwarzamy i jeszcze więcej postrzegamy, im więcej postrzegamy, tym więcej przetwarzamy i rozumiemy ${ }^{13}$.

11 Z. Władyka-Łuczak [publikacja w przygotowaniu].

12 J. Głowacki, Przekroczyć próg, w: Z. Władyka-Łuczak, Przekroczyć próg, BILBO Graficzne Studio Komputerowe, Łódź 2001, s. 7.

13 „Widzenie nie jest tylko biernym, biologicznym aktem odbioru doznań wzrokowych [...]. Poznajemy świat nie przez to, że go tylko widzimy, lecz przez to, że myślimy i poznajemy, co mówi nam każde z doznań wzrokowych, jaki fragment wiedzy o świecie wnosi oko - słowem, przez analizę doznań wzrokowych, ich uogólnienie i ponowne sprawdzenie. O zakresie naszego widzenia 
Porównanie dwóch rzeczywistości, inspirującej i interpretowanej, to chyba najprostsza definicja pracy rzeźbiarza z modelem. Nie chodzi tu o prosty podział: na rzeźbę jako interpretowaną rzeczywistość, oraz na modela jako rzeczywistość inspirującą. Rzeźba, będąc przedmiotem nacechowanym podmiotowością interpretacyjną, pełni jednocześnie rolę inicjatora inspiracji. Zadanie rzeźbiarza polega na ciągłej obserwacji rzeczywistości, na odnajdywaniu i wskazywaniu punktów narracji inspirująco-interpretacyjnych i właściwym ich zestawieniu. $Z$ mojego punktu widzenia rzeczywistość interpretowana istnieje w chwili tworzenia. Wraz z powstaniem zamienia się w rzeczywistość inspirującą ${ }^{14}$.

Nie może być inaczej:

każde działanie zawsze przebiega w równoczasowości, gdyż nie ma ani przeszłości, ani przyszłości inaczej niż jako koncepty komunikacyjne, przy pomocy których zaspokajane są te lub inne potrzeby systemu, ponieważ więc zawsze obecny jest tylko dany stan w równoczasowości (a równoczasowości nie można kontrolować, gdyż ona właśnie się odbywa), potrzebujemy jako systemy kognitywne przerywaczy procesów, by móc operowaćc ${ }^{15}$.

Musi się zatem niejako samoistnie, bez żadnej kontroli dokonać domknięcie stanu równoczasowości, inaczej stanu inspiracji, by powstał koncept komunikacyjny.

Czym jest ów koncept? W przypadku działań wizualnych może być to szkic, czasem kolejny etap powstającego rysunku, malunku, rzeźby.

Czym jest wspomniany wyżej przerywacz procesów? To kolejny etap wewnętrznych negocjacji - akceptacji lub negacji tego, co powstało do tej pory, inaczej rzeczywistość inspirująca.

Strzemiński tłumaczy to w sposób następujący:

Malarstwo jest rzeczą wzroku, ręki i umysłu. Należy wciąż kształtować wzrok, widzieć to, czego nie dostrzegano dawniej, rozszerzać zawartość wzrokową, wzbogacać kulturę patrzenia i sprawność ręki. Umysł powinien porządkować i wprowa-

decyduje nie jakieś «przyrodzone», «normalne» widzenie, lecz proces pracy zachodzącej we wzajemnym związku i wzajemnej zależności pomiędzy widzeniem biologicznym a naszą myślą. W ten sposób powstaje świadomość wzrokowa, która rozstrzyga o tym, jaką [liczbę] elementów świata poznaliśmy przy pomocy naszego oka" (W. Strzemiński, Teoria widzenia, s. 53).

14 Z. Władyka-Łuczak, dz. cyt.

15 M. Fleischer, Kapitat..., s. 19. 
dzać system ten w zakres, jaki zdobywa wzrok, a czasami nawet wskazywać mu drogę poszukiwańn ${ }^{16}$.

Reasumując, postawa przedtwórcza to inaczej rzeczywistość interpretowana, występująca jako przerywacz procesów komunikacyjnych. Postawa twórcza to rzeczywistość inspirująca, inicjacja przekazu artystycznego występująca jako koncept komunikacyjny. Razem składają się na wzór działań, który możemy zapisać następująco:

Postawa przedtwórcza $\rightarrow$ postawa twórcza $[\ldots] \rightarrow$ postawa przedtwórcza

Nieznana jest liczba wymiany postaw przedtwórczych i twórczych, pewne natomiast jest, że proces ten otwiera i zamyka postawa przedtwórcza. Pracę rozpoczynamy i kończymy w ramach konceptu komunikacyjnego, przekazując dzieło do nowych wewnętrznych i zewnętrznych negocjacji znaczeń. Postawa twórcza zamieniona zostaje w koncept, który może, choć nie musi, stać się rzeczywistością inspirującą.

Czy zawsze postawa przedtwórcza przechodzi płynnie w postawę twórczą? $\mathrm{W}$ retrospekcji pisałam:

Każda rzeźba jest wyzwaniem wymagającym procesu poszukiwań, ciągłej negacji i akceptacji tego, co się zrobiło do tej pory. Redukcja błędnych rozwiązań siłą rzeczy powiązana jest $\mathrm{z}$ odczuwaniem afektów negatywnych. Znane jest mi doskonale uczucie podwyższonej irytacji związane z pełną negacją własnej osoby. Zawsze jednak potrafię wykorzystać twórczo ten stan, jeszcze nigdy nie odeszłam wtedy od sztalugi czy kawaletu. Zawsze jest to droga do sukcesu. Odchodzę, gdy przeżywam emocjonalną pustkę i w tej pustce odczuwam klęskę. Twórczość jest emocjonalnie kosztowna, wymaga odwagi, zmierzenia się z własnymi słabościami, a przede wszystkim cierpliwości w oczekiwaniu na upragnione przyjście odczucia auto-akceptacji [...] Odejść to nie znaczy zapomnieć. Tak naprawdę nie wiem, jak to się dzieje. Nie jest tak, że pomiędzy odejściami od sztalugi czy kawaletu bezustannie myślę o swojej pracy. Naprawdę nie wiem, jak to się dzieje, że drugie, czasem kolejne podejście zmienia mnie na tyle, że potrafię dojść do celu. [...] Jestem uparta. Jeszcze nigdy nie porzuciłam rozpoczętego zadania. Czasem trwa to długo, ale zawsze zostaje zamknięte ${ }^{17}$.

16 W. Strzemiński, Bilans modernizmu, „Europa”, w: Powidoki życia. Władysław Strzemiński i prawa dla sztuki = Afterimages of life: Władysław Strzemiński and rights for art, red. J. Lubiak, Muzeum Sztuki w Łodzi, Łódź 2012, s. 115-116.

17 Z. Władyka-Łuczak, dz. cyt. 
Co prowokuje zainicjowanie postawy twórczej? Nie wiem. Z przeprowadzonej autoetnograficznej analizy wynika, że istnieją dwie drogi: jedna spontaniczna, druga prowokowana.

Spontaniczna jest zjawiskowa i niekontrolowana. Prowokowana wymaga poszukiwań, ćwiczeń, umiejętności i samokontroli. Wypracowuje się ją latami. Temat ten poruszałam już w artykule pt. Geopoetyka materii rzeźbiarskiej - poszukiwanie rzeczywistości:

Rysownik, malarz lub rzeźbiarz, zanim przekroczy linię dzielącą go od sztuki, uczy się rzeczywistości. Poznaje ją nie tylko poprzez obserwację i odtwarzanie świata zewnętrznego, ale również własnej osoby. Nie chodzi tu tylko o wrażliwość, intuicję czy wiedzę, ale o sposób postawienia kreski, położenia plamy, naciśnięcia, narzucenia czy odjęcia materiału rzeźbiarskiego. [...] [Trwało to] Przez lata, kiedy to wyrzeźbić ptaka znaczyło - dowiedzieć się, w jaki sposób jest on zbudowany, w jaki sposób łączy się np. pas barkowy ze skrzydłami, jakie są odległości między nimi, jaki jest ich kształt. Jednocześnie poznawałam możliwości ludzkiego ciała - swojego ciała. Zdobywałam wiedzę, że ręka połączona z barkiem to cyrkiel, a naturalny ruch wykonywany przez człowieka to elipsa lub jej fragment. Dowiedziałam się również, że staw łokciowy, nadgarstek oraz anatomiczna konstrukcja dłoni to kolejne narzędzia zakreślające kolejne elipsy. Nakreślane elipsy napotykają opór materii. W jakim stopniu i jak to też nauka rzeczywistości ${ }^{18}$.

Obserwacja świata zewnętrznego, obserwacja siebie - to właśnie warsztat prowokacji. Świadomość zamierzeń i działań. Należy nie tylko znać cel, ale i wiedzieć, jak go osiągnąć, znać wartość pozostawianych śladów gestów, ruchu ręki w materii. Wśród twórców sztuk wizualnych często pojawia się słowo „szukaj” - szukaj formy, kształtu, koloru, faktury itp. Doskonale je rozumiemy, szukaj to inaczej: obserwuj, ucz się rzeczywistości, wyciągaj wnioski.

Nie jest tak, że - przystępując do pracy - znam ostateczny wygląd dzieła. Znam główne założenia, ale ta znajomość nie jest równoznaczna z fotograficzną wizją wyglądu tworzonego. Pod powiekami nie mam obrazu skończonej rzeźby. Dopiero muszę znaleźć jej ostateczną formę. Nieustannie przechodzę przez ten proces. Nieustannie go doświadczając, przekonuję się, że tworzyć oznacza szukać. Artysta to inaczej człowiek, który bezustannie szuka inspiracji [...].

Jestem przekonana, że poszukiwanie formy polega na ciągłej obserwacji rzeczywistości. Polega na akceptowalnym przeniesieniu zauważonych elementów z przed-

18 Z. Władyka-Łuczak, Geopoetyka materii rzeźbiarskiej, w: Strategie twórcze w działaniu, red. G. Habrajska, J. Ślósarska, Wydawnictwo Primum Verbum, Łódź 2016, s. 362. 
miotu inspirującego do przedmiotu tworzonego. Szukanie formy jest aktem oceny własnych działań. Skonstruowana forma zostanie zaakceptowana lub odrzucona ${ }^{19}$.

W jaki sposób wygląda nauka obserwacji i jak wyglądają te poszukiwania? Za przykład niech posłuży moja relacja z przebiegu pracy nad portretem Rajmunda Rembielińskiego, bohatera „Pomnika Początków Miasta Łodzi”.

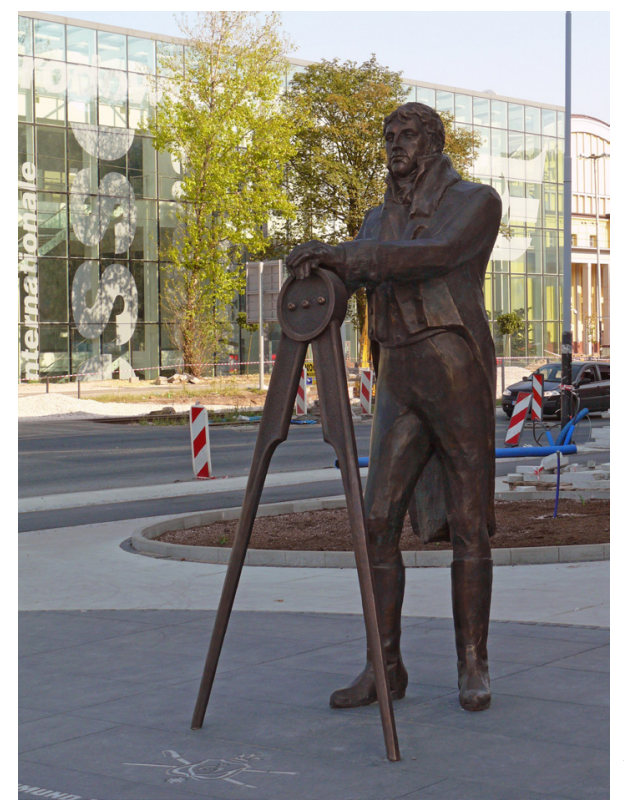

Fot. 2. "Pomnik Początków Miasta Łodzi”,

Z. Władyka-Łuczak.

Fot. Z. Władyka-Łuczak.

Twarz bohatera to jeden z ważniejszych obszarów pomnikowej rzeźby. Należy pod uwagę wziąć wiele czynników, takich jak: podobieństwo do przedstawianej postaci, prawidłowe osadzenie, proporcje, układ, kierunek spojrzenia. Poświęca się jej wiele uwagi.

Stworzyłam wówczas kolejno dwie twarze. Jednak pierwszej nie mogłam zaakceptować. Oceniłam ją jako zbyt młodą i zbyt realistyczną, z za mało wyrazistymi rysami. Druga z nich, zaaprobowana, nie miała wspomnianych błędów.

W podanym przykładzie czasem twórczym była ta chwila, w której podjęłam decyzję o zrzuceniu gliny ze złego portretu. Miałam za sobą okres przedtwórczych poszukiwań, a przed sobą czas warsztatowej realizacji celu na podstawie zdobytych doświadczeń. Podjęcie decyzji, chwila inspiracji była krótka. Najdłużej trwała nauka rzeczywistości, rozpoznanie portretowanej twarzy. Realizacja - właściwe wyrzeźbienie portretu trwało tyle, ile potrzebowałam, by mechanicznie odtworzyć poznaną już rzeczywistość.

19 Z. Władyka-Łuczak, dz. cyt. 

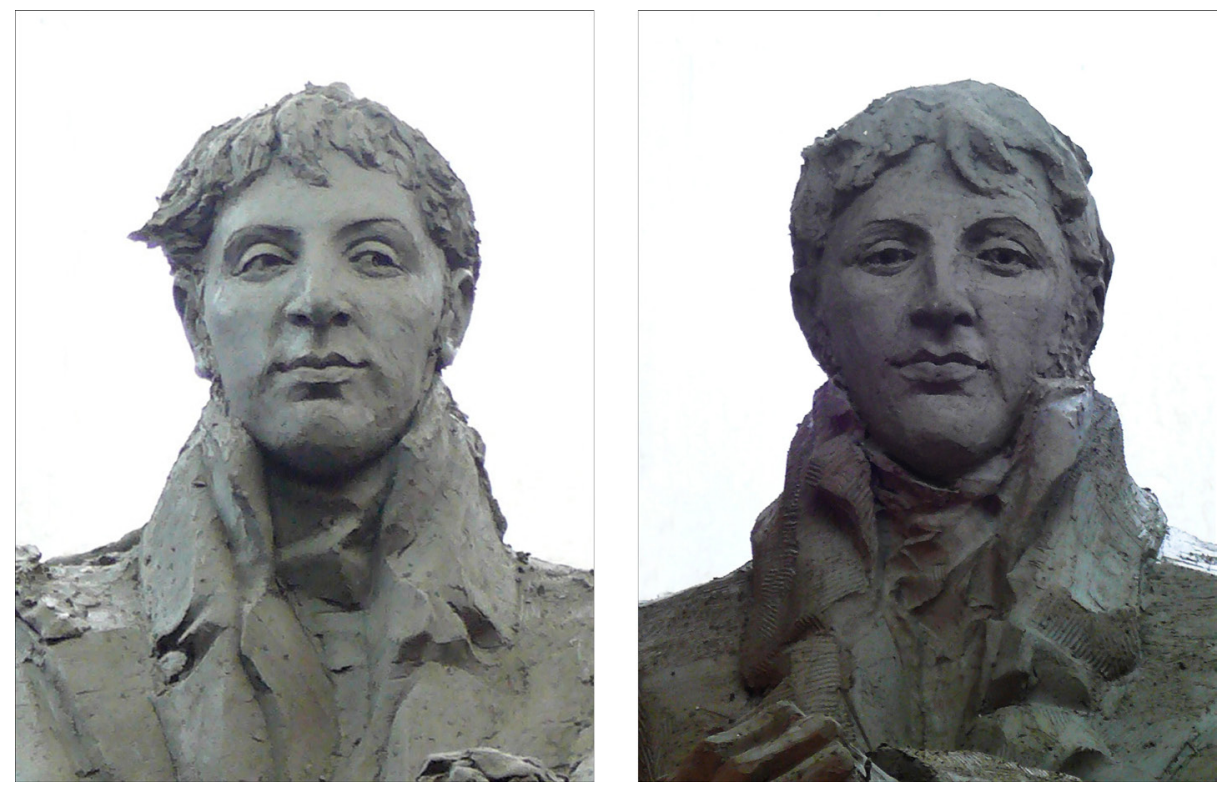

Fot. 3. Prace przy portrecie Rajmunda Rembielińskiego. Zdjęcie po lewej: odrzucona wersja portretu, zdjęcie po prawej: wersja zaakceptowana.

Fot. Z. Władyka-Łuczak.

Twórca w stanie inspiracji przedtwórczych tkwi nieustannie. Obserwacja rzeczywistości to podstawa, na której kształtuje się sprawność widzenia artystycznego. Prawdą jest też, że wraz z postępem sprawności manualnej wzrasta świadomość widzenia. W moim przypadku proces ten nie przebiega równolegle. Zawsze świadomość widzenia przewyższa umiejętności manualne. Nowa rzeźba to nowe wyzwanie wymagające odrębnego opracowania. Znalezienie odpowiedzi na takie wyzwanie to nowy bagaż doświadczeń, nowe umiejętności i nowy zakres świadomości widzenia.

Niezależnie od tego, czy pracuję nad rzeźbą, która została zlecona, czy rzeźbię tylko dla siebie, proces inicjacji stanów przedtwórczych i twórczych wygląda podobnie. Zawsze rozpoczynam pracę od zgromadzenia materiałów. Mówiąc inaczej, postępuję tak, jak chcą tego konstruktywiści, przeprowadzam rozpoznanie elementów odnoszących się do różnorakich systemów dyferencyjnych. Interesuje mnie wtedy wszystko. Mam świadomość, że oczekiwany stan przejścia ze stanu przedtwórczego do twórczego może nastąpić w każdej chwili. Dzisiaj, po wielu latach, już wiem, że nie warto oceniać wartości zebranych materiałów, inicjacja stanu twórczego i tak przyjdzie sama.

Czy tylko ja o tym wiem? Sądzę, że podobnie przebiegała inicjacja z 2018 roku, kiedy członkowie Komitetu Obrony Demokracji postanowili powiesić koszulki 
z napisem KONSTYTUCJA na istniejących od dawna rzeźbach. Rozumiem, że $\mathrm{w}$ tym przypadku postawa przedtwórcza związana była $\mathrm{z}$ negacją rzeczywistości politycznej oraz z poszukiwaniem środków wyrazu (materii) wypowiedzi artystycznej. Postawa twórcza pojawiła się w chwili zestawienia ze sobą fizycznych nośników idei, a więc koszulki z napisem KONSTYTUCJA, oraz istniejących rzeźb. Zaspokojenie postanowionego celu, wykreowanie czytelnego dla wszystkich konceptu komunikacyjnego, stworzyło podstawę do pojawienia się nowych postaw przedtwórczych. Jakich? Na odpowiedź na to pytanie jeszcze czekamy...

Dla twórcy jednym z niezawodnych sposobów zdobywania doświadczeń jest szkicownik. Ja też taki mam. Notując, nie czuję presji. Wszystko, co w nim powstaje, może okazać się przydatne. Ma służyć przejściu ze stanu przedtwórczego w stan twórczy. I tylko tyle. Większosś tych rysunków czeka wraz ze mną na przejście, na czas nowego zaistnienia, tak jak ten znajdujący się niżej.

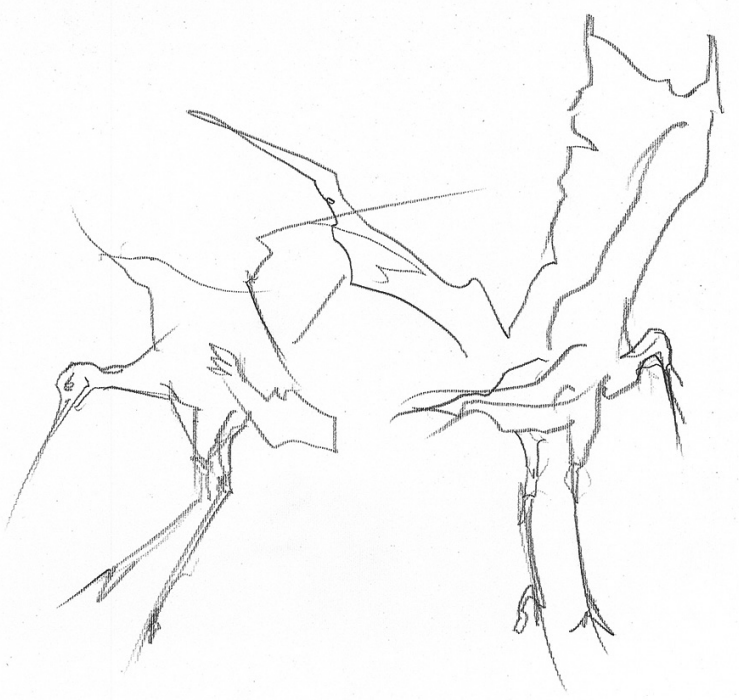

Rys. 1. Szkic młodych bocianów, Z. Władyka-Łuczak 


\section{Bibliografia}

Fleischer M., Dwa rodzaje reprodukcji systemów - dywersyfikacja i dyferencjacja, $\mathrm{w}$ : Komunikatywizm w Polsce. Wybrane zagadnienia z teorii i praktyki, red. G. Habrajska, Primum Verbum, Łódź 2011.

Fleischer M., Kapitał niestety nie( )ludzki, Libron - Filip Lohner, Kraków 2014.

Głowacki J., Przekroczyć próg, w: Z. Władyka-Łuczak, Przekroczyć próg, BILBO Graficzne Studio Komputerowe, Łódź 2001, s. 7.

Luhmann N., Pisma o sztuce i literaturze, Wydawnictwo Naukowe „Scholar”, Warszawa 2016.

Oświadczenie Komitetu Obrony Demokracji, 3.08.2018, https://www.ruchkod.pl/ oswiadczenie-komitetu-obrony-demokracji/ [dostęp: 20.08.2018].

Strzemiński W., Bilans modernizmu, „Europa”, w: Powidoki życia. Władysław Strzemiński i prawa dla sztuki = Afterimages of life: Władysław Strzemiński and rights for art, red. J. Lubiak, Muzeum Sztuki w Łodzi, Łódź 2012, s. 115-116.

Strzemiński W., Teoria widzenia, Muzeum Sztuki w Łodzi, Łódź 2016.

Wallis M., Przeżycie i wartość. Pisma z estetyki i nauki o sztuce 1931-1949, Wydawnictwo Literackie, Kraków 1968.

Władyka-Łuczak Z., [publikacja w przygotowaniu].

Władyka-Łuczak Z., Geopoetyka materii rzeźbiarskiej, w: Strategie twórcze w działaniu, red. G. Habrajska, J. Ślósarska, Wydawnictwo Primum Verbum, Łódź 2016.

Zofia Władyka-Łuczak

\section{Inicjacja przekazu artystycznego}

\section{Streszczenie}

Przedstawiony artykuł to próba odpowiedzi na pytanie: Kiedy i z jakiego powodu pojawia się inicjacja przekazu artystycznego?

Analiza kierująca do końcowego wniosku została przeprowadzona na podstawie autoetnograficznej analizy z procesu tworzenia Pomnika Początków Miasta Łodzi. Głównym jej wątkiem było poszukiwanie granicy pomiędzy stanem przedtwórczym a twórczym w trakcie pracy artysty nad dziełem.

Z przeprowadzonej analizy wynika, że: „,[n]iezależnie od tego, czy pracuję nad rzeźbą, która została zlecona, czy rzeźbię tylko dla siebie, proces inicjacji stanów przedtwór- 
czych i twórczych wygląda podobnie. Zawsze rozpoczynam pracę od zgromadzenia materiałów. Postępuję tak, jak chcą tego konstruktywiści, przeprowadzam rozpoznanie elementów odnoszących się do różnorakich systemów dyferencyjnych. [...] Mam świadomość, że oczekiwany stan przejścia ze stanu przedtwórczego do twórczego może nastąpić w każdej chwili. Dzisiaj, po wielu latach, już wiem, że nie warto oceniać wartości zebranych materiałów, inicjacja stanu twórczego i tak przyjdzie sama”.

Istotą zainicjowania postawy twórczej jest wykształcenie umiejętności obserwacji otaczającej artystę rzeczywistości, a co istotniejsze - wykształcenie umiejętności wydobywania z niej tego, co już w całym tym skomplikowanym procesie jest tym, co zwykliśmy nazywać inspiracją. Granica stanu przedtwórczego a twórczego powstaje w chwili, w której artysta podejmuje decyzję o przeniesieniu zauważonego fragmentu rzeczywistości do tworzonego właśnie dzieła.

Ocena wartości dzieła sztuki to osobne zagadnienie, które w artykule zostało pominięte.

Słowa kluczowe: twórczość, komunikacja wizualna, kompozycja, struktura formalna obrazu, narracja formalna, teoria widzenia, komunikat werbalny, komunikat wizualny.

\title{
Artistic Inspiration: How to Provoke Some Inspirational States for Creative Actions
}

\author{
Summary
}

The article "Initiation of the artistic message" is an attempt to answer the question: When and for what reason does the initiation of the artistic message appear?

The analysis leading to the final conclusion was carried out on the basis of autoethnographic analysis from the process of creating the „Monument to the Origins of the City of Lodz". The main theme was the search for the border between the precreative state and the creative one during the artist's work on the work.

The analysis shows that: „Regardless of whether I'm working on a sculpture that was commissioned or sculpted only for myself, the process of initiating pre-creative and creative states looks similar. I always start my work from collecting materials. I proceed as the constructivists want, I carry out the recognition of elements relating to various differential systems. [...] I am aware that the expected state of transition from pre-creative to creative state can occur at any time. Today, after many years, I know that it is not worth assessing the value of the collected materials, the initiation of the creative state will come by itself". 
The essence of initiating a creative attitude is to develop the skill of observing the reality surrounding the artist, and what is more important to develop the skills of extracting from it what already in all this complicated process is what we used to call - inspiration. The boundary of the pre-creative and creative state arises at the moment when the artist makes the decision to transfer the noticed fragment of reality to the work being created.

The evaluation of the value of a work of art is a separate issue that has been omitted in the article

Keywords: artistic inspiration, creativity, visual communication, composition, formal structure of the image, formal narration, theory of vision, verbal communication, visual communication.

Zofia Władyka-Łuczak - mgr sztuki, doktor nauk humanistycznych w zakresie kulturoznawstwa, rzeźbiarz i pracownik naukowy Zakładu Teorii i Praktyki Komunikacji Uniwersytetu Łódzkiego, zainteresowania badawcze: komunikacja wizualna, estetyka, teoria sztuki. 